\title{
Faktor-Faktor yang Berhubungan dengan Perilaku Cuci Tangan Pakai Sabun (CTPS) pada Mahasiswa Universitas Jambi Selama Pandemi COVID-19
}

\author{
Factors Related to Hand Washing Behavior With Soap in Universitas Jambi Students \\ During Covid-19 Pandemic
}

\author{
Esra Sianipar, M. Ridwan, Ismi Nurwaqiah Ibnu, Guspianto, La Ode Reskiaddin \\ Program Studi Ilmu Kesehatan Masyarakat, Universitas Jambi, Jambi
}

\begin{abstract}
Abstrak
COVID-19 merupakan penyakit menular yang cepat menyebar. Di Indonesia terdapat jumlah kasus terkonfirmasi positif COVID-19 1.863.031 sedangkan di Provinsi Jambi 108 kasus per tanggal 07 Juni 2021. Cuci Tangan Pakai Sabun dapat mencegah penularan COVID-19 di kampus. Penelitian ini bertujuan untuk menganalisis faktor-faktor yang berhubungan dengan perilaku cuci tangan pakai sabun (CTPS) pada mahasiswa Universitas Jambi selama pandemi COVID-19. Penelitian ini menggunakan pendekatan kuantitatif dengan desain studi Cross-Sectional. Jumlah Sampel yang digunakan sebanyak 106 mahasiswa yang dipilih menggunakan teknik Multistage Sampling. Berdasarkan hasil uji statistik, hubungan pengetahuan dan sarana prasarana dengan perilaku CTPS masing-masing memiliki nilai pvalue sebesar 0,191 dan 0,804 ( $\mathrm{p}>0,05)$ sedangkan untuk hubungan sikap dan dukungan teman sebaya dengan perilaku CTPS memiliki nilai $p$-value sebesar 0,030 dan 0,000 ( $p<0,05)$. Pengetahuan dan sarana prasarana tidak memiliki hubungan yang signifikan dengan perilaku CTPS, sedangkan sikap dan dukungan teman sebaya memiliki hubungan yang signifikan dengan perilaku CTPS.
\end{abstract}

Kata Kunci: Mahasiswa, Cuci Tangan Pakai Sabun (CTPS), COVID-19.

\begin{abstract}
Abstrak
COVID-19 is a fast-spreading infectious disease. In Indonesia, there are 1,863,031 confirmed positive cases of COVID-19 while in Jambi Province 108 cases as of 07 June 2021. Washing hands with soap can prevent transmission of COVID-19 on campus. This study aims to analyze the factors related to the behavior of washing hands with soap (CTPS) in Jambi University students during the COVID-19 pandemic. This research uses a quantitative approach with a cross-sectional study design. The number of samples used were 106 students who were selected using the Multistage Sampling technique. Based on the results of statistical tests, the relationship between knowledge and infrastructure with CTPS behavior has $\mathrm{p}$-values of 0.191 and 0.804 , respectively ( $\mathrm{p}>0.05$ ), while the relationship between attitudes and peer support with CTPS behavior has a p-value of 0.030. and 0.000 ( $p<0.05$ ). Knowledge and infrastructure do not have a significant relationship with CTPS behavior, while attitudes and peer support have a significant relationship with CTPS behavior.
\end{abstract}

Keywords: Students, Washing Hands with Soap (CTPS), COVID-19.

$\begin{array}{ll}\text { Korespondensi } & \text { : Esra Sianipar } \\ \text { E-mail } & \text { : esranataliasianipar@gmail.com }\end{array}$ 


\section{PENDAHULUAN}

Coronavirus Disease (COVID-19) adalah virus yang dapat menimbulkan penyakit mulai ditandai dengan memiliki gejala ringan hingga gejala berat. COVID-19 merupakan penyakit yang sebelumnya belum pernah dikenali dan merupakan penyakit jenis baru. Jenis virus penyebab COVID-19 ini dikenal dengan sebutan Sars-CoV-2. Virus corona merupakan zoonosis (ditularkan antara hewan dan manusia)(1). Virus ini dapat menular melalui droplet yang dikeluarkan melalui mulut dan hidung saat batuk, atau bersin atau berbicara dengan orang sekitar. Droplet ini masuk ke saluran pernafasan sampai ke paru-paru melalui ACE2 atau angiotensin converting enzyme 2 yang ditemukan di sel alveolar tipe II paru-paru. Virus ini menggunakan permukaan yang berduri (spike) yang mengandung glikoprotein untuk mengikat ACE2 dan memasuki sel induk(2).

Saat ini terdapat 223 negara di dunia yang terpapar oleh COVID-19. Per tanggal 07 Juni 2021 terdapat jumlah kasus terkonfirmasi positif COVID-19 di seluruh dunia mencapai 173.005.553 kasus dengan jumlah kematian 3.727.605 kasus. Sedangkan di Indonesia terdapat jumlah kasus terkonfirmasi positif per tanggal 07 Juni 2021 yaitu sebanyak 1.863.031 kasus dengan jumlah kematian 51.803 kasus, jumlah kasus aktif 99.663 kasus, dan jumlah kasus sembuh 1.711.565 kasus. Di Provinsi Jambi per tanggal 06 Juni 2021 terkonfirmasi COVID19 dengan kasus positif sebanyak 108 kasus, jumlah kematian 2 kasus dan jumlah kasus sembuh 61 kasus. Meskipun vaksin COVID-19 telah hadir di Indonesia, akan tetapi vaksin COVID-19 bukanlah obat. Vaksin COVID-19 hanya bisa mendorong pembentukan kekebalan spesifik terhadap penyakit COVID-19 supaya terhindar dari tertular maupun sakit berat lainnya. Vaksin COVID-19 belum bisa melindungi secara jangka panjang. Oleh karena itu, selama belum ditemukan vaksin yang efektif dan aman, upaya perlindungan yang mampu kita lakukan yaitu disiplin/ mematuhi protokol kesehatan(3).

Berdasarkan hal diatas, salah satu cara yang dapat dilakukan dalam pencegahan penularan COVID-19 ini yaitu Cuci Tangan Pakai Sabun (CTPS). Cuci Tangan Pakai Sabun (CTPS) merupakan salah satu tindakan yang dapat mengurangi/ menghilangkan serta mencegah bakteri di tangan. Untuk mencegah berpindahnya segala kuman, tindakan CTPS sendiri akan lebih efektif jika dilakukan dengan menggunakan sabun serta air bersih yang mengalir. Jika tidak cuci tangan dengan sabun dan air mengalir, maka tangan tidak akan bersih dari kuman dan kuman itu sendiri tetap masuk kedalam tubuh melalui makanan yang kita pegang dan ujungnya dapat menyebabkan penyakit(4). Berdasarkan laporan Survei Demografi dan Kesehatan Indonesia (SDKI) 2017, persentase rumah tangga daerah tempat tinggal perkotaan perilaku cuci tangan menggunakan sabun dan air sebesar 97,1\%, hanya menggunakan air sebesar 2,1\%, menggunakan sabun tanpa air sebesar 0,4\%, tempat cuci tangan tetap sebesar 87,3\%, dan tempat cuci tangan tidak tetap sebesar 8,5\%(5).

Perilaku atau kebiasaan higienes Cuci Tangan Pakai Sabun (CTPS), mampu mencegah penularan COVID-19. Perilaku cuci tangan khususnya cuci tangan pakai sabun, masih menjadi tujuan penting dalam promosi kesehatan, terutama PHBS. Perilaku cuci tangan pakai sabun memang bukan kebiasaan sehari-hari masyarakat umum. Rendahnya perilaku cuci tangan pakai sabun dan tingginya tingkat efektifitas perilaku cuci tangan pakai sabun dalam mencegah penularan penyakit, maka sangat penting upaya promosi kesehatan peningkatan cuci tangan tersebut(6).

Perilaku CTPS (Cuci Tangan Pakai Sabun) dipengaruhi oleh banyak faktor diantaranya 
yaitu pengetahuan, sikap, motivasi, keyakinan, dll. Melalui tingkat kesehatan, Green menganalisis perilaku manusia. Faktor yang mempengaruhi kesehatan individu ada dua yaitu behavior causes (faktor perilaku) serta non behavior causes (faktor diluar perilaku). Kemudian perilaku itu sendiri ditentukan oleh tiga faktor yaitu faktor predisposisi (predisposing factors) seperti pengetahuan dan sikap, faktor pemungkin (enabling factors) seperti ketersediaan sarana prasarana, dan faktor pendorong atau penguat (reinforcing factors) seperti dukungan teman sebaya(7).

Penelitian tentang pengetahuan, sikap, dan perilaku Cuci Tangan Pakai Sabun pada mahasiswa FKIK UIN Syarif Hidayatullah Jakarta 2015 yang dilakukan oleh Irma Sari Muliadi melaporkan dari 100 responden sebanyak 58\% responden memiliki pengetahuan baik tentang Cuci Tangan Pakai Sabun, 99\% responden memiliki sikap baik tentang Cuci Tangan Pakai Sabun, dan 67\% responden memiliki perilaku baik tentang Cuci Tangan Pakai Sabun. Secara statistik, hasil analisis menggambarkan ada hubungan dengan CTPS(8). Selanjutnya penelitian yang dilakukan oleh Haryani, dkk (2021) tentang pengetahuan dan perilaku mencuci tangan pasa siswa SMK sebagai upaya pencegahan COVID-19 menunjukkan bahwa 75\% atau 90 siswa SMK berpengetahuan baik, 85,8\% atau 103 siswa SMK berperilaku baik. Secara statistik, hasil analisis menggambarkan ada hubungan dengan CTPS dan disarankan untuk meningkatkan upaya pencegahan terhadap COVID-19 dengan 3M yaitu mencuci tangan menggunakan sabun, memakai masker, dan menjaga jarak.

Berdasarkan penelitian yang dilakukan oleh Murwanto (2017) menyatakan perilaku Cuci Tangan Pakai Sabun (CTPS) di SMP sebesar 55,9\% atau sudah cukup baik sedangkan berdasarkan faktor yang mempengaruhi terdapat sembilan variabel bernilai positif diantaranya pengetahuan, nilai-nilai, citra diri, ketersediaan CTPS, kepercayaan, kemudahan dalam mendapatkan CTPS, peran guru, orangtua, serta teman sekolah dan terdapat tiga variabel dimana nilainya negatif yaitu 50\% diantaranya variabel persepsi, sikap, serta peran petugas kesehatan(9).

Universitas Jambi ialah salah satu Perguruan Tinggi yang mempunyai mahasiswa terbanyak di Provinsi Jambi yang jumlahnya mencapai 26.203 mahasiswa sampai pada tahun 2020. Sehingga penularan COVID-19 lebih besar terjadi. Survey awal yang telah dilakukan oleh peneliti, dominan mahasiswa tidak mencuci tangan pakai sabun ketika keluar masuk ruangan kampus serta setelah menyentuh benda fasilitas umum di kampus. Selain itu, sarana cuci tangan pakai sabun tidak semua tersedia di setiap ruangan. Hanya terdapat satu atau dua tempat CTPS di depan gedung masing-masing fakultas. Hand sanitizer yang dapat digunakan sebagai sarana pengganti CTPS juga tidak terdapat disetiap ruangan. Oleh sebab itu, hal ini bisa menimbulkan terjadinya penularan COVID-19 di lingkungan Universitas Jambi sehingga proses belajar mengajar mahasiswa kedepannya juga akan berdampak dan perkuliahan menjadi tidak efektif. Berdasarkan hal tersebut, peneliti sangat tertarik melakukan penelitian tentang Faktor-Faktor yang Berhubungan dengan Perilaku Cuci Tangan Pakai Sabun (CTPS) pada Mahasiswa Universitas Jambi Selama Pandemi COVID-19.

\section{METODE}

Penelitian ini menggunakan jenis penelitiankuantitatif dengan desain cross sectional menggunakan teknik Multistage Sampling. Sampel pada penelitian ini adalah mahasiswa Fakultas Hukum, Fakultas Kedokteran dan Ilmu Kesehatan, dan Fakultas Sains dan Teknologi 
Universitas Jambi angkatan tahun 2017 - 2019 yang berjumlah 106 responden.

\section{HASIL PENELITIAN}

Tabel 1 memperlihatkan jenis kelamin laki-laki 29 orang $(27,4 \%)$ dan perempuan 77 orang (72,6\%). Angkatan 2017 sebanyak 28 orang (26,4\%), angkatan 2018 sebanyak 32 orang $(30,2 \%)$, dan angkatan 2019 sebanyak 46 orang $(43,4 \%)$. Dari Tabel 2, dapat diketahui bahwa perilaku CTPS baik dan kurang baik sama besarnya yaitu 53 orang (50\%), pengetahun baik 77 orang $(72,6 \%)$ dan kurang baik 29 orang $(27,4 \%)$, sikap positif 62 orang $(58,5 \%)$ dan negatif 44 orang $(41,5 \%)$, dukungan teman sebaya baik 56 orang $(52,8 \%)$ dan kurang baik 50 orang $(47,2 \%)$, sarana prasarana tersedia 866 orang $(81,1 \%)$ dan tidak tersedia 20 orang $(18,9 \%)$.

\section{KARAKTERISTIK RESPONDEN}

Tabel 1. Distribusi Karakteristik responden diUniversitas Jambi Tahun 2021

\begin{tabular}{|c|c|c|c|c|}
\hline No. & \multicolumn{2}{|c|}{ Karakteristik Responden } & $\mathbf{N}$ & $\%$ \\
\hline \multirow{2}{*}{1.} & \multirow{2}{*}{ Jenis Kelamin } & Laki-Laki & 29 & 27,4 \\
\hline & & Perempuan & 77 & 72,6 \\
\hline \multirow{3}{*}{2.} & \multirow{3}{*}{ Angkatan } & 2017 & 28 & 26,4 \\
\hline & & 2018 & 32 & 30,2 \\
\hline & & 2019 & 46 & 43,4 \\
\hline \multirow{3}{*}{3.} & \multirow{3}{*}{ Semester } & 4 & 45 & 42,5 \\
\hline & & 6 & 33 & 31,1 \\
\hline & & 8 & 28 & 26,4 \\
\hline
\end{tabular}

\section{ANALISIS UNIVARIAT}

Tabel 2. Distribusi Responden Berdasarkan Variabel pada Mahasiswa Universitas Jambi Tahun 2021

\begin{tabular}{|c|c|c|c|c|}
\hline No. & Variab & & $\mathbf{N}$ & $\%$ \\
\hline \multirow[b]{2}{*}{1.} & \multirow{2}{*}{ Perilaku CTPS } & Baik & 53 & 50 \\
\hline & & Kurang Baik & 53 & 50 \\
\hline \multirow{2}{*}{2.} & \multirow{2}{*}{ Pengetahuan } & Baik & 77 & 72,6 \\
\hline & & Kurang Baik & 29 & 277,4 \\
\hline \multirow{2}{*}{3.} & \multirow{2}{*}{ Sikap } & Positif & 62 & 58,5 \\
\hline & & Negatif & 44 & 41,5 \\
\hline \multirow{2}{*}{4.} & \multirow{2}{*}{ Dukungan Teman Sebaya } & Baik & 56 & 52,8 \\
\hline & & Kurang Baik & 50 & 47,2 \\
\hline \multirow{2}{*}{5.} & \multirow{2}{*}{ Sarana Prasarana } & Tersedia & 86 & 81,1 \\
\hline & & Tidak Tersedia & 20 & 18,9 \\
\hline
\end{tabular}

Berdasarkan hasil penelitian menunjukkan bahwa dari 77 responden yang pengetahuan baik terdapat 42 orang memiliki perilaku CTPS baik dan 35 orang memiliki perilaku CTPS kurang baik. Sedangkan dari 29 responden yang pengetahuan kurang baik terdapat 11 orang memiliki perilaku CTPS baik dan 18 orang memiliki perilaku CTPS kurang baik. Diperoleh nilai $\mathrm{p}$-value adalah $0,191(\mathrm{p}>0,05)$. Dari 62 responden yang sikap positif terdapat 37 orang mempunyai perilaku CTPS baik dan 25 orang mempunyai perilaku CTPS kurang baik. Sedangkan dari 44 responden yang sikap negatif terdapat 16 orang mempunyai 
perilaku CTPS baik dan 28 orang mempunyai perilaku CTPS kurang baik. Diperoleh nilai pvalue adalah $0,030(\mathrm{p}<0,05)$.

Dari 56 responden yang dukungan teman sebaya baik terdapat 38 orang mempunyai perilaku CTPS baik dan 18 orang mempunyai perilaku CTPS kurang baik. Sedangkan dari 50 responden yang dukungan teman sebaya kurang baik terdapat 15 orang mempunyai perilaku CTPS baik dan 35 orang mempunyai perilaku CTPS kurang baik. Diperoleh nilai p-value adalah $0,000(\mathrm{p}<0,05)$.

Dari 86 responden yang sarana prasarana tersedia terdapat 44 orang mempunyai perilaku CTPS baik dan 42 orang memiliki perilaku CTPS kurang baik. Sedangkan dari 20 responden yang sarana prasarana tidak tersedia terdapat 9 orang mempunyai perilaku CTPS baik dan 11 orang mempunyai perilaku CTPS kurang baik. Diperoleh nilai p-value adalah 0,804 ( $p>0,05)$.

\section{PEMBAHASAN}

\section{Hubungan Pengetahuan dengan Perilaku Cuci Tangan Pakai Sabun}

Hasil analisis hubungan antara pengetahuan dengan Perilaku Cuci Tangan Pakai Sabun diperoleh nilai $p$-value sebesar 0,191 . Hal ini menunjukkan bahwa nilai $p>0,05$, yang artinya tidak ada hubungan yang signifikan antara pengetahuan dengan Perilaku Cuci Tangan Pakai Sabun pada mahasiswa Universitas Jambi.

Hasil penelitian ini sejalan dengan penelitian yang dilakukan oleh Barrett dan Cheung (2021) tentang Knowledge, Socio-Cognitive Perceptions and the Practice of Hand Hygiene and Social Distancing During the COVID-19 Pandemic:a Cross-sectional Study of UK University Students, bahwa hasil penelitian ini menemukan tidak ada hubungan yang signifikan antara pengetahuan dengan perilaku Cuci Tangan Pakai Sabun dengan nilai p-value sebesar 0,239 ( $\mathrm{p}>0,05)(10)$.

Pengetahuan adalah hasil mengetahui objek melalui indera yang dimiliki seseorang (mata, hidung, telinga, dll.) atau hasil persepsi manusia. Pengetahuan yang dihasilkan dipengaruhi oleh perhatian subjek dan lamanya persepsi(11).

\section{Hubungan Sikap dengan Perilaku Cuci Tangan Pakai Sabun}

Hasil analisis hubungan antara sikap dengan Perilaku Cuci Tangan Pakai Sabun diperoleh nilai $\mathrm{p}$-value sebesar 0,030. Hal ini menunjukkan bahwa nilai $\mathrm{p}<0,05$, yang artinya ada hubungan yang signifikan antara sikap dengan Perilaku Cuci Tangan Pakai Sabun pada mahasiswa Universitas Jambi. Hasil penelitian ini sejalan dengan penelitian yang dilakukan oleh Solikah Titin dan Tri Wahyuni Suksesi (2018) tentang Hubungan Tingkat Pengetahuan, Sikap, dan Motivasi dengan Perilaku Cuci Tangan Pakai Sabun (CTPS) pada Siswa Sekolah Dasar Negeri Tridadi Sleman DIY, bahwa terdapat hubungan yang signifikan antara sikap dengan perilaku Cuci Tangan Pakai Sabun dengan nilai p-value sebesar 0,001 $(\mathrm{p}<0,05)(12)$.

Sikap adalah daya pendorong untuk bertindak ataupun merespons suatu stimulus atau obyek yang timbul dari pengalaman serta perkembangan suatu individu. Sikap individu dapat dikatakan positif jika suka terhadap suatu objek psikologi sedangkan sikap individu dapat dikatakan negatif jika ia tidak suka terhadap objek psikologi. Sikap mahasiswa terhadap cuci tangan pakai sabun bisa mempengaruhi dilakukan atau tidak dilakukannya perilaku cuci tangan oleh mahasiswa tersebut. 


\section{Hubungan Dukungan Teman Sebaya dengan Perilaku Cuci Tangan Pakai Sabun}

Hasil analisis hubungan antara dukungan teman sebaya dengan Perilaku Cuci Tangan Pakai Sabun didapatkan nilai p-value sebesar 0,000. Hal ini menunjukkan bahwa nilai $\mathrm{p}<$ 0,05 , yang artinya ada hubungan yang signifikan antara dukungan teman sebaya dengan Perilaku Cuci Tangan Pakai Sabun pada mahasiswa Universitas Jambi. Hasil penelitian ini sejalan dengan penelitian yang dilakukan oleh Waruwu (2019) tentang Faktor-Faktor yang Berhubungan dengan Perilaku Cuci Tangan Pakai Sabun (CTPS) pada Siswa SD Swasta Al Ulum Kecamatan Medan Area Tahun 2018, bahwa hasil penelitian ini menemukan ada hubungan yang signifikan antara dukungan teman sebaya dengan perilaku Cuci Tangan Pakai Sabun dengan nilai $\mathrm{p}$-value sebesar 0,039 ( $\mathrm{p}<0,05)(13)$.

Dukungan sosial teman sebaya adalah sumber dukungan yang paling penting bagi remaja karena pada masa remaja mereka akan lebih banyak menghabiskan waktu bersama dengan teman-temannya dibandingkan dengan orangtua. Melalui dukungan sosial dari teman sebaya maka remaja akan mendapatkan saran dan penegetian yang akan membantu mereka untuk memahami situasi mereka dan dapat membuat penyesuaian yang tepat berdasarkan potensi mereka.

Dukungan teman sebaya di kampus dapat berupa pengaruh positif dan negatif. Dalam hal ini maka peran dukungan teman sebaya sangat diperlukan karena mahasiswa umumnya lebih banyak berinteraksi dengan teman mahasiswa lainnya di kampus khususnya dalam mengajak untuk membiasakan Cuci Tangan Pakai Sabun selama pandemi COVID-19(14).

\section{Hubungan Sarana Prasarana dengan Perilaku Cuci Tangan Pakai Sabun}

Hasil analisis hubungan antara sarana prasarana dengan Perilaku Cuci Tangan Pakai Sabun diperoleh nilai p-value sebesar 0,804. Hal ini menunjukkan bahwa nilai $\mathrm{p}>0,05$, yang artinya tidak ada hubungan yang signifikan antara sarana prasarana dengan Perilaku Cuci Tangan Pakai Sabun pada mahasiswa Universitas Jambi.

Hasil penelitian ini juga didukung dengan penelitian yang dilakukan oleh Kartika, dkk (2016) tentang Faktor-Faktor yang Berhubungan dengan Perilaku Cuci Tangan Pakai Sabun pada Siswa Sekolah Dasar Negeri Sambiroto 01 Kota Semarang, bahwa hasil penelitian ini menemukan tidak ada hubungan yang signifikan antara sarana prasarana dengan perilaku Cuci Tangan Pakai Sabun dengan nilai p-value sebesar 0,383 ( p > 0,05)(15).

Green (1980) mengemukakan bahwa pembentukan perilaku manusia dipengaruhi oleh tiga faktor, dan satu diantaranya yaitu faktor pendorong (enabling factor). Faktor pendorong adalah penyebab suatu perilaku terjadi. Faktor tersebut diantaranya: lingkungan fisik, sarana kesehatan, atau sumber daya pendukung khusus, dan terjangkaunya fasilitas kesehatan. Sarana Cuci Tangan Pakai Sabun ialah sarana yang harus tersedia serta bisa dimanfaatkan dalam pelaksanaan perilaku Cuci Tangan Pakai Sabun dengan benar, meliputi tempat mencuci tangan dengan air bersih mengalir, sabun, dan handuk/tissue kering.

\section{KESIMPULAN DAN SARAN}

Tidak terdapat hubungan yang signifikan antara pengetahuan dan sarana prasarana dengan perilaku Cuci Tangan Pakai Sabun dengan nilai p-value sebesar 0,191 dan 0,804 (p > 0,05). Terdapat hubungan antara sikap dan dukungan teman sebaya dengan perilaku Cuci Tangan Pakai Sabun dengan nilai p-value sebesar 0,030 dan 0,000 ( $<<0,05)$. Diharapkan 
kepada pihak kampus Universitas Jambi supaya menggencarkan lagi protokol kesehatan khususnya cuci tangan pakai sabun lewat media sosial kampus seperti Instagram, Facebook, dan Youtube dalam pembentukan sikap serta meningkatkan dukungan teman sebaya. Sebaiknya mahasiswa Universitas Jambi lebih meningkatkan sikap serta dukungan teman sebaya untuk CTPS guna mencegah penularan COVID-19 di kampus. Selain itu, mahasiswa melalui organisasi kemahasiswaan dapat melahirkan duta COVID-19 yang nantinya akan berperan aktif untuk mengajak teman mahasiswa lainnya dalam pencegahan COVID-19 termasuk perilaku CTPS.

\section{DAFTAR PUSTAKA}

1. Syafrida S, Hartati R. Bersama Melawan Virus Covid 19 di Indonesia. SALAM J Sos dan Budaya Syar-i. 2020;7(6):495-508.

2. Keputusan Menteri Kesehatan Republik Indonesia. Keputusan Menteri Kesehatan Republik Indonesia Nomor HK.01.07/MenKes/413/2020 Tentang Pedoman Pencegahan dan Pengendalian Corona Virus Disease 2019 (Covid-19). MenKes/413/2020. 2020;2019:207.

3. Satgas Covid-19. Peta Sebaran Covid-19 Tahun 2021 [Internet]. Available from: https://covid19.go.id/peta-sebaran

4. Octa A. Hubungan Pengetahuan Dan Sikap Terhadap Perilaku Cuci Tangan Pada Masyarakat Kelurahan Pegirian. J PROMKES. 2019;7(1):1.

5. BKKBN, BPS, Kementrian Kesehatan U. Survei Demografi dan Kesehatan Indonesia 2017 Profinsi DKI Jakarta. 2018;271. Available from: http://demografi.bps.go.id/phpfiletree/sdki/BahanAjarSDKI2007/Lainnya/Publikasi SDKI 2002-2003/RingkasanSDKI02-03.pdf

6. Maryunani A. Perilaku Hidup Bersih dan Sehat (PHBS). Jakarta: CV. Trans Info Media; 2017.

7. Notoatmojo S. Metode Penelitian Kesehatan. Jakarta: Rineka Cipta; 2010.

8. Muliadi IS. Pengetahuan, Sikap, Perilaku hidup bersih dan Sehat Pada Mahasiswa Fkik Uin Syarif Hidayatullah Jakarta Tahun 2015. UNI Syarif Hidayatullah, Jakarta; 2015.

9. Murwanto B. Faktor Perilaku Cuci Tangan Pakai Sabun (CTPS) di SMP. J Kesehat. 2017;8(2):269.

10. Barrett C, Cheung KL. Knowledge, socio-cognitive perceptions and the practice of hand hygiene and social distancing during the COVID-19 pandemic: a cross-sectional study of UK university students. BMC Public Health. 2021;21(1):1-18.

11. Notoatmojo S. Promosi Kesehatan dan Perilaku Kesehatan. Jakarta: Rineka Cipta; 2012.

12. Solikah T, Sukesi TW. Hubungan Tingkat Pengetahuan, Sikap, Dan Motivasi Dengan Perilaku Cuci Tangan Pakai Sabun (Ctps) Pada Siswa Sekolah Dasar Negeri Tridadi, Sleman, Diy. Fak Kesehat Masy Univ Ahmad Dahlan. 2019;1-15.

13. Waruwu. Faktor-Faktor yang Berhubungan dengan Perilaku Cuci Tangan Pakai Sabun (CTPS) pada Siswa SD Swasta Al Ulum Kecamatan Medan Area Tahun 2018. Universitas Sumatera Utara; 2019.

14. Fatimah E. Psikologi Perkembangan: Perkembangan Peserta Didik. Bandung: CV. Pustaka Setia; 2010.

15. Kartika M, Widagdo L, Anung S. Faktor - Faktor Yang Berhubungan Dengan 
Keterampilan Cuci Tangan Pada Anak Kelas IV Dan V Di SDN 179 Kecamatan Rumbai Kota Pekanbaru. J Ners Indones. 2016;4(5):339-46. 